\title{
Development and Performance Evaluation of a Low Cost Waste-Water Treatment Plant 1Fasinmirin J.T. and 20 lufayo A.A.
}

\section{Abstract}

The design, development and performance evaluation of a low cost waste-water treatment plant had been carried out. The aim was to harness the usefulness of waste-waters from residential, institutional and commercial sources. The facultative lagoon method of waste-water treatment was adopted. Biological analysis of treated effluents showed a decrease in coliform count from $18 \times 10^{2}$ to $16 \times 10^{2}$ per $100 \mathrm{ml}$ after the first 28 days of treatment. There was a drastic reduction in viable plate count from $6.4 \times 10^{4}$ to $2.1 \times 10^{3} \mathrm{cfu} \mathrm{ml^{-1 }}$ after filtration through activated carbon, fine sand and coarse sand medium. A decrease in chemical constituents (Zinc, Manganese and Copper) of treated waste-water was observed. However, no significant reduction in Iron and Nickel concentration was observed during the treatment period. Also, the $\mathrm{pH}$ of collected effluent samples which were found to be in the range of alkalinity before treatment become acidic to neutral after the 49 days of treatment in the development treatment plant. This research is useful in the management of scarce water resource especially in areas where water poverty is significantly felt during dry seasons.

Keywords: Waste-water; Toxicity; Micro-organisms; Filtration tank; Low-cost; Colony forming Unit (CFU)

\section{Introduction}

very community produces both
liquid and solid wastes. The liquid portion, which is wastewater, is essentially the water supply to the community after it has been fouled by a variety of uses. Looking at the source of generation, wastewater could be defined as a combination of the liquid or water carried waste removed from residence, institutions, commercial and industrial establishments, together with such ground water, surface water and storm water as may be present (Metcalf and Eddy, 1993; Rose, 1986; Shuval, 1991). These wastewaters, if discharged directly into water courses or land could cause serious damage to many forms of life. In addition, water sources and land utilized by man either as a portable water for washing and bathing, could present potential risk of transmission of a large number of water related diseases, while in the case of land may destroy and damage the crop planted and form breeding ponds for insects and other microorganisms which are harmful to man, plants and animals (F.A.O., 1985 and 1992) .

When wastewater is untreated and allowed to accumulate, decomposition of its organic content can lead to the production of large quantity of malodorous gases (Horan, 1991; Pescod and Arar, 1988). To ensure that such problems are avoided or minimized, attention should be paid to the treatment and disposal of wastewaters (Mara and Cairncross, 1989). A suitable treatment method to ensure that water is harmless and still useful to man for domestic purpose or growth of aquatic life as well as for irrigation in agriculture is important (Arthur, 1983; Levy, 1984; Madramootoo et al., 1997). The practice of using wastewaters for irrigation is common in many arid and semiarid areas of the world, including the United States. Indirect human consumption of wastewaters occurs when surface waters, particularly rivers receiving wastewater discharges, are used for water supply. These surface sources, along with an increasing number of groundwater resources, are contaminated by the waste discharges from communities, industrial activities, agricultural and urban runoff, and storm water. Field studies conducted using wastewater for vegetable irrigation have found higher bacterial counts on crop portions that mature underground or near the surface of the soil (Armon et al. 1994; Rosas et al. 1984). Since it is commonly asserted that the vascular systems of plants are sterile, direct contact of the water with edible portions is the principal transmission route of pathogens from water to crop (Gerba and Smith 2005). Water treatment plants have produced water that is considered safe for human use, although these finished waters may contain low levels of organic chemicals which may be potentially harmful following long-term ingestion (Neal, 1982). Many processes in a wastewater treatment plant are designed to mimic the natural treatment processes that occur in the environment, whether that environment is a natural water body or the ground. If not overloaded, bacteria in the environment will consume organic contaminants, although this

${ }^{1}$ Departamento de Solos, Centro de Ciências Rurais, Universidade Federal de Santa Maria, Brazil fasinmirin johnson@yahoo.com

${ }^{2}$ Department of Agricultural Engineering, Federal University of Technology, Akure, Nigeria. 
will reduce the levels of oxygen in the water and may significantly change the overall ecology of the receiving water. Native bacterial populations feed on the organic contaminants, and the numbers of diseasecausing microorganisms are reduced by natural environmental conditions such as predation or exposure to ultraviolet radiation (Beychok, 1971). Remarkable research breakthroughs had been made in the design and development of wastewater treatment plants most especially in the developed countries. However, most of these machines are owned either by communities or municipals due to the huge cost involved. It is important therefore to meet the growing environmental challenges posed by wastewaters through the development of domestically affordable and cost reducing recycling plant. This research was aimed at designing, developing, and test of a low-cost wastewater treatment plant from locally sourced raw materials.

\section{Materials and Methods}

Description of the low cost wastewater treatment plant

The components of the low-cost wastewater treatment plant include the followings:

1) Storage tank (Facultative lagoon)

A plastic drum, which absorbs heat better and faster during the day, was used as facultative lagoon of collected wastewater. The facultative lagoon was designed to hold the wastewater long enough for much of the solids in the wastewater to settle and for many disease-causing bacteria, parasites, and viruses to either die off or settle out. Time also allows treatment to reduce the overall organic strength of the wastewater, or its biochemical oxygen demand (BOD). The cylindrical drum which is $0.5 \mathrm{~m}$ in diameter and $0.65 \mathrm{~m}$ high has a valve installed just at $0.1 \mathrm{~m}$ from its base. The valve was used to metre a predetermined volume of wastewater into the treatment line. The plastic drum was so chosen because of its usefulness in the biological treatment process of water.

\section{2) Hose}

A transparent plastic pipe $0.018 \mathrm{~m}$ in diameter and $2 \mathrm{~m}$ long was connected directly to the valve at the base of the storage tank and was used to convey wastewater from the storage tank to filtration tank via a shower cap that serves to break wastewater into droplets in form of rainfall. The spray shower diameter is $0.08 \mathrm{~m}$ and since it has to spray the wastewater evenly across the surface it was raised to a height $(0.45 \mathrm{~m})$ from the surface of the filtration tank considering the angle at which the shower sprays (Figure 1).

\section{3) Filtration tank}

The filtration tank was constructed from metal plate precisely gauge 18 . The rectangular filtration tank is $1 \mathrm{~m}$ high, $0.5 \mathrm{~m}$ long and $0.5 \mathrm{~m}$ wide as shown in Figure 2. The tank has two compartments: the filter medium where various filtering materials were placed, and the filtrate compartment where completely treated water is stored. The filter medium compartment is $0.6 \mathrm{~m}$ from the top of the filtration tank and the storage compartment is 0.4 from the base.

\section{4) Multi-medium filter bed}

This comprises of coarse sand filter, fine sand filter and activated carbon as shown in Figure 2. On the average, the diameters of the coarse sand, fine sand and activated charcoal were 6 , 2 and $2 \mathrm{~mm}$, respectively. The sand media were used to filter solid particles and lighter particles that are contained in the wastewater and activated carbon derived from wood was used to dissolve chemicals such as oil and other oleophilic substances that stick to its surface while the water passes during the treatment process. The activated carbon is capable of removing all man-made and naturally occurring substances such as: alachlor, atrazine, benzene, carbofuran, carbon tetrachloride, chlorobenzene, dibromochloropropane (DBCP), O, Pdechlorobenzines, forms of dichloroethylens, 1, 2-dechloropropane, cis-1,3dichloropropylene, toxaphene, chlordane, radon, lindane, simazine, toluene, xylenes and others. 



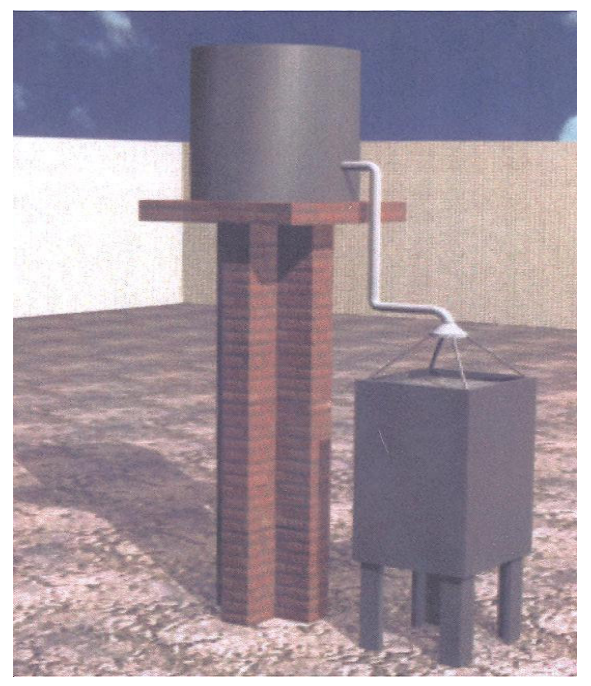

Figure 1. Sectional view of the waste treatment plant

\section{Performance Evaluation Method}

a) Waste-Water Sampling

Domestic waste-water samples were collected from some selected residential buildings located in Akure city centre, Ondo State, Nigeria, where there were drainages and water closets that convey wastewaters from homes to municipal outlets. Wastewater samples were collected from three randomly selected locations along the drainage outlet. Three samples were collected simultaneously from each of the three sampling point. This was to characterize the natural variability that occurs under environmental conditions and to effectively determine the point source pollution levels of the wastewater samples. A total of nine samples were collected and immediately transferred to the chemistry laboratory of the Federal University of Technology, Akure for biological and chemical analysis.

\section{b) Wastewater Treatment Method \\ b.1) Biological process}

The facultative lagoon (pond) method, which naturally settles into three fairly distinct layers or zones, was used for the treatment of the collected wastewater samples. This method involves treatment and stabilization of waste by a combination of aerobic, anaerobic and facultative bacteria. The facultative pond consists of three zones: surface zone where aerobic bacteria and algae exist in a symbiotic relationship, anaerobic zone (base) where

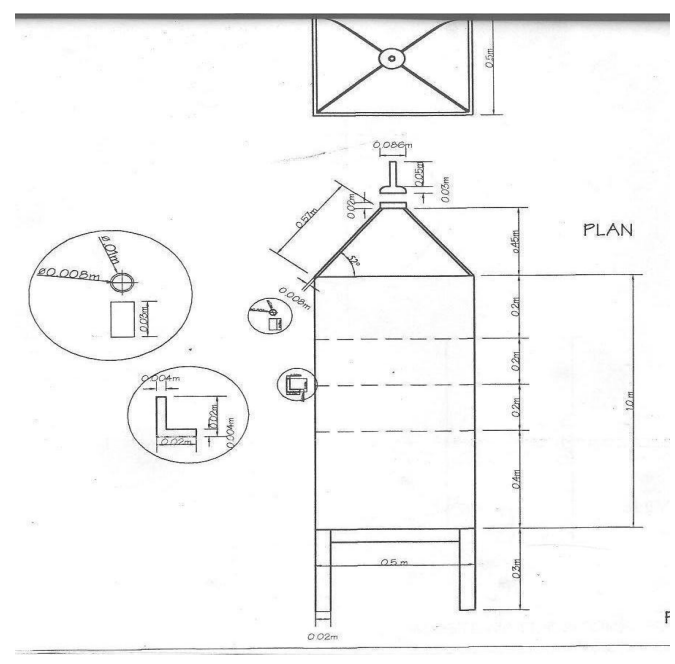

Figure 2. The schematic diagram of the filtration tank

accumulated solids are actively decomposed by anaerobic bacteria and the intermediary zone that is partly aerobic and partly anaerobic. The decomposition of organic wastes by facultative bacteria takes place in the intermediary zone.

Different conditions exist in each zone, and wastewater treatment takes place in all three. The collected waste-water in storage tank was opened to the atmospheric condition for a period of 49 days. A specified detention time of between 18 to 60 days was adopted, which is the minimum period recommended to provide complete endogenous respiration of residual solids (Metcalf and Eddy, 1993). In the aerobic photosynthetic pond, oxygen supply comes from atmosphere and algae photosynthesis. The oxygen released by the algae through the process of photosynthesis was used by bacteria in the aerobic degradation of organic matter. The nutrients and carbon dioxide released in this degradation are, in turn, used by the algae.

The anaerobic zone is the layer at the very bottom of the lagoon where no oxygen is present. This area includes a layer of sludge, which forms from all the solids that settle out from the wastewater. In the anaerobic zone, wastewater is treated by anaerobic bacteria; microscopic organisms, such as certain protozoa; and sludge worms, all of which thrive in anaerobic conditions. The most important bacteria in the anaerobic zone of the pond is of the methanogenic group which 
degrade acetic acid and propionic acid. They have a very slow growth rates and as a result, their metabolism is usually considered ratelimiting in the anaerobic treatment of organic waste.

\section{b.2) Chemical process}

The chemical treatment was carried out in the filtration tank with the aid of the multimedia filter, made up of sand and activated carbon. The design of the filtration tank was carried out taking the followings into consideration: The size of the filter unit, the number of filters, the loading method. The design of the size of the filter unit was based on the quantity of water being worked on and the loading technique.

The biologically treated waste-water flow through the valve and hose into the filtration tank through a shower into the filter medium made up of coarse sand which filters the coarse solid particles; The fine sand which reduces the size of particles that passes through the filter; and the activated carbon which removes taste and odour and reduces some possible chemical constituents that are harmful when in excess in water. The filtrate was collected at intervals of 10 minutes per sample and then sent to the laboratory for analysis.

\section{Statistical Analysis}

Results of treated wastewater were subjected to statistical analysis such as ANOVA and the means were compared using least significant difference (LSD) at the 0.001 level of probability.

Results and Discussions

The result of the biological analysis of raw waste-water is presented in Table 1 . The viable plate count was lowest $\left(4.8 \times 10^{4}\right)$ in waste-water sample collected at $0700 \mathrm{Hr}$ and highest $\left(8.6 \times 10^{4}\right)$ in sample collected at 0736 Hr. The increase in bacteria population from the viable plate count between the hours 0700 and 0736 may be due to washing of toilets, urination and bathing from adjoining houses at the site of waste collection. Gradual decrease in bacteria population was observed from 0821 to $0831 \mathrm{Hr}$. The decrease in bacteria population may been caused by clean water that run freely when most people started leaving home for their works.

The results of biological treatment of wastewater are presented in Figures $3-11$. There were drastic reductions in bacteria population of wastewater within the first 14 days after collection. The reduction in viable plate count may be a result of rise in solar radiation which resulted to an increase in temperature of wastewater samples and thereby killing most of the bacteria that are close to the surface (aerobic zone). This observation was peculiar to all the sampled wastewaters except for sample $A_{2}$ which had an increase in viable plate count from 7.3 to 7.6 CFU/ml during the 7 and 14 days after treatment, respectively. Between the $14^{\text {th }}$ and $28^{\text {th }}$ days of waste-water treatment, there was increase in bacteria population and this was due to the reproduction of bacteria left in the anaerobic zone and the decline in the ambient temperature due to increased relative humidity. However, from the $28^{\text {th }}$ to the $49^{\text {th }}$ day of treatment, the bacteria population reduced due to rise in temperature and drastic decomposition of organic content in the wastewater causing the bacteria to die fast thereby reducing the viable plate count to as low as $2.3 \times 10^{3}$ as against $6.4 \times 10^{4} \mathrm{CFU} / \mathrm{ml}$ initially observed before filtration in sample $A_{1}$. The reduction could be attributed to the content of the filter medium (dry coarse sand and fine sand) at relatively high temperature $\left(30^{\circ} \mathrm{C}\right)$ and the activated carbon that removed traces of oils from the treated water samples. The curve of viable plate count on function of days after treatment gave the lowest coefficient of determination $r^{2}=0.74$ in treated sample $A_{1}$ and highest $r^{2}=0.96$ in treated sample $B_{2}$. The were no significant difference in the means of the viable plate count of samples A, B and C for all days of observation at the $\mathrm{P}=0.001$. Multiple comparison of means of the replicates of wastewaters after treatment also showed no significant difference at $\mathrm{P}=0.001$.

\section{Conclusion}

This report identifies the sources of waste-water, its constituents, and designed a simple and low-cost method of treating wastewaters. The developed waste-water treatment plant was found effective in waste-water treatment considering the appreciable reduction in coliform counts from all samples after being treated for a number of days. The lowest viable plate counts were obtained during the $49^{\text {th }}$ day after treatment, thus, making the treated water suited for a number of purposes such as irrigation and factory use. Furthe treatment of the waste-water samples could translate to severe reduction of coliform 
count and this definitely will result to better options in the use of the recycled water. Also, the development of this type of a wastewater treatment plant which employs the use of locally sourced raw materials is well encouraged in this research since the total of

\section{References}

Armon, R., Dosoretz, C. G., Azov, Y., and Shelef, G. 1994. Residual contamination of crops irrigated with effluent of different qualities: a field study. Water Science and Technology, 30(9), 239-248.

Arthur, J.P. 1983. Note on the design and operation of waste stabilization pond in warm climates of developing countries. World Bank Technical Paper No. 6, World Bank, Washington DC. pp $1-35$.

Beychok, M.R. 1971. "Performance of surfaceaerated basins". Chemical Engineering Progress

Symposium Series 67 (107): 322-339.

F.A.O. 1985. Water quality for agriculture. In R.S. Ayer and D.W. Westcot. F.A.O. Irrigation and Drainage, paper 29, Rev. 1, F.A.O. Rome. pp174 - 176.

F.A.O. 1992. Waste-water treatment and use in agriculture. M.B. Pescod. F.A.O. Irrigation and Drainage, paper 47, F.A.O. Rome. pp125 130.

Gerba, C. P., and Smith, J. E. 2005. Sources of pathogenic microorganisms and their fate during land

application of wastes. Journal of Environmental Quality, 34, 42-48.

Horan, N.J. 1991. Biological Wastewater Treatment Systems. Theory and Operation. John Wiley \& Sons, New York. pp1 - 8, 17, $19,28-36,67-81$.

Levy, R. 1984. Chemistry of Irrigated Soil. Published by Van Nostrand Reinhold Company Inc. Pp142 - 164. materials and production costs of the teatment plant is below $\$ 350$ comparatively with the outrageous costs of procuring imported wastewater treatment plant, the cost of which could be as high as $\$ 380,574$ depending on the size and configurations.

Madramootoo, C.A., Johnston, W.R. and Willardson, L.S. 1997. Management of agricultural drainage water quality. F.A.O. Water Report 13, Rome. pp17.

Mara, D. And Cairncross, S. 1989. Guideline for the safe use of wastewater and excreta in agriculture and aquaculture. Measure for public health protection, World Health Organisation, Geneva. pp187.

Metcalf, B. And Eddy, D. 1993. Wastewater Engineering, Treatment, Disposal and Re-use. $3^{\text {rd }}$ edition, New York; Mc Graw-Hill Inc. Pp1 $-10,20-24,56-118,180-255,212-218$, $339-864$.

Neal, R. A. 1982. Evaluating potential health risks of consuming reused water. J. Am Water Works Assoc. 74:638-641.

Pescod, M.B. and Arar, A. 1988. Treatment and use of sewage effluent for irrigation. Proceedings of the F.A.O. regional seminar on the treatment and use of sewage effluent for irrigation. Nicosia, Cyprus. pp380-385.

Rosas, I., Baez, A., \& Coutino, M. 1984. Bacteriologicalquality of crops irrigated with wastewater in the Xochimilco Plots, Mexico City, Mexico. Applied and Environmental Microbiology, 47(5), 1074-1079.

Rose, J.B. 1986. Microbial aspect of wastewater reuse for irrigation. CRC critical review in environmental control. 16(3). pp231 $-256$.

Shuval, H.I. 1991. Health guidelines and standards for wastewater reuse in agriculture. Historical perspectives, Water Science and Technology 23 (10/12), pp2037 - 2080. 
Table 1. Initial viable plate count of raw wastewater samples collected from different points on $13^{\text {th }}$ February, 2006

\begin{tabular}{ccccc}
\hline Sample & Time of collection & MPN* & Coliform count(per 100 ml) & Viable plate count \\
\hline $\mathrm{A}_{1}$ & $0700 \mathrm{hr}$ & 555 & $<18 \times 10^{2}$ & $4.8 \times 10^{4}$ \\
$\mathrm{~A}_{2}$ & $0703 \mathrm{hr}$ & 555 & $<18 \times 10^{2}$ & $6.2 \times 10^{4}$ \\
$\mathrm{~A}_{3}$ & $0706 \mathrm{hr}$ & 555 & $<18 \times 10^{2}$ & $6.8 \times 10^{4}$ \\
$\mathrm{~B}_{1}$ & $0736 \mathrm{hr}$ & 55 & $<18 \times 10^{2}$ & $7.2 \times 10^{4}$ \\
$\mathrm{~B}_{2}$ & $0738 \mathrm{hr}$ & 555 & $<18 \times 10^{2}$ & $8.6 \times 10^{4}$ \\
$\mathrm{~B}_{3}$ & $0741 \mathrm{hr}$ & 555 & $<18 \times 10^{2}$ & $6.4 \times 10^{4}$ \\
$\mathrm{C}_{1}$ & $0821 \mathrm{hr}$ & 555 & $<18 \times 10^{2}$ & $7.2 \times 10^{4}$ \\
$\mathrm{C}_{2}$ & $0826 \mathrm{hr}$ & 555 & $<18 \times 10^{2}$ & $5.4 \times 10^{4}$ \\
$\mathrm{C}_{3}$ & $0831 \mathrm{hr}$ & 555 & $<18 \times 10^{2}$ & $6.1 \times 10^{4}$ \\
\hline MPN* - Most Probable Number (probability according to McCrady)
\end{tabular}

MPN* - Most Probable Number (probability according to McCrady)

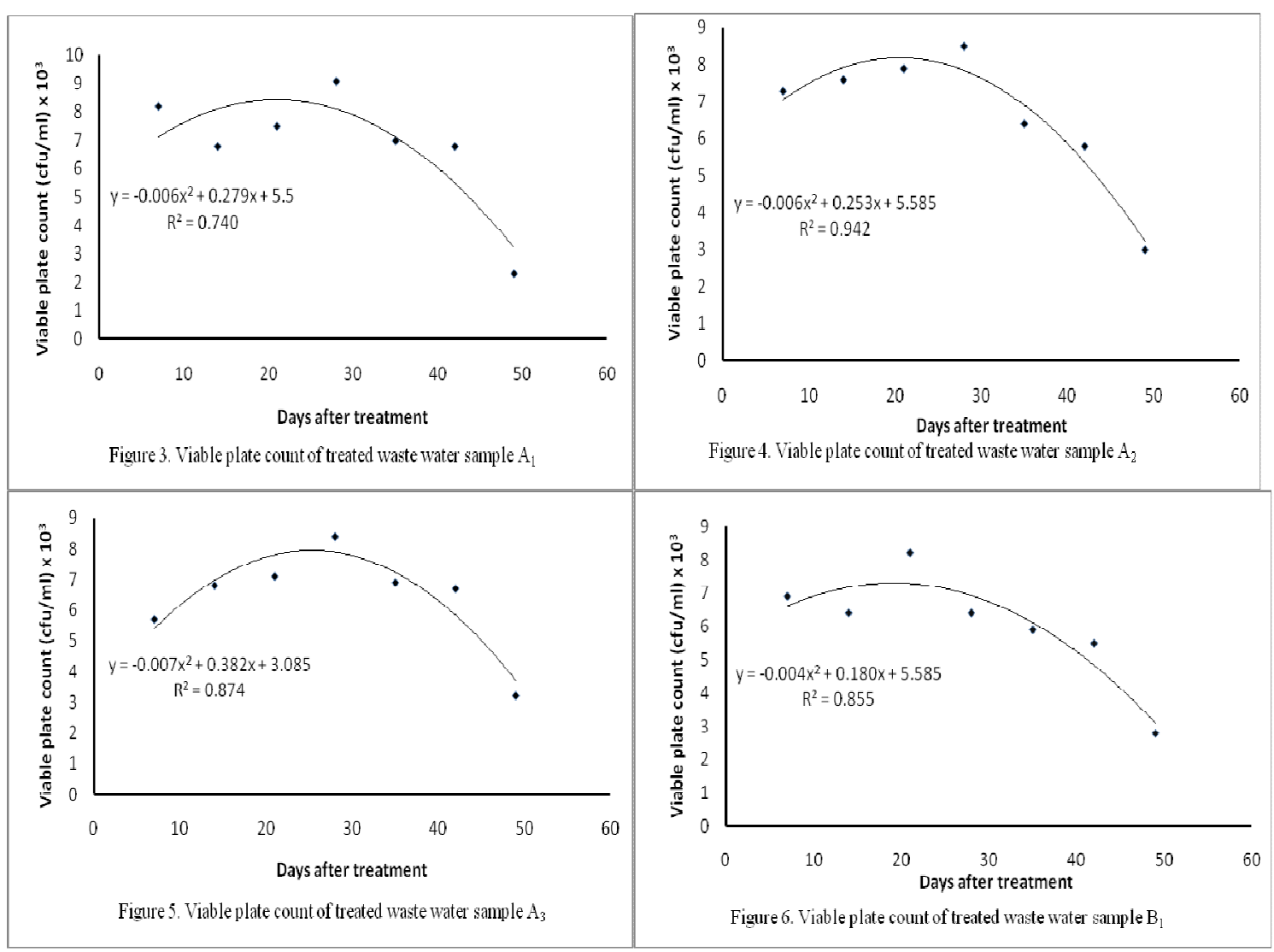




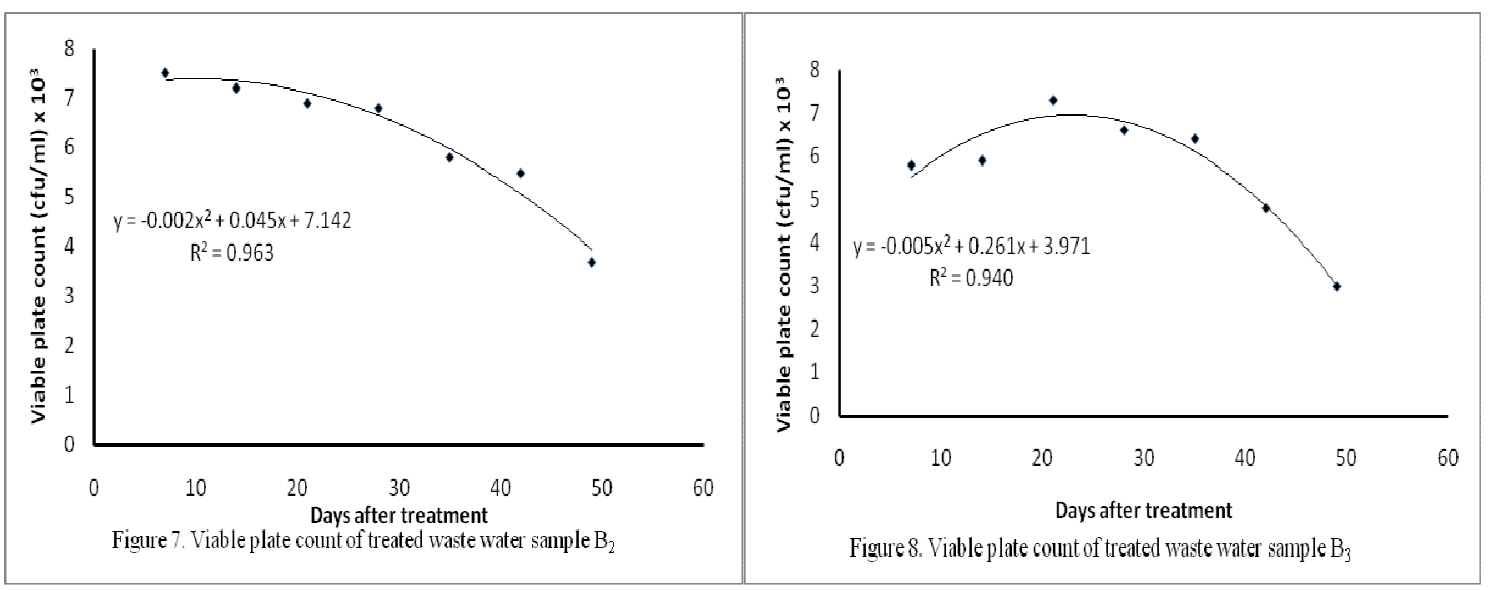

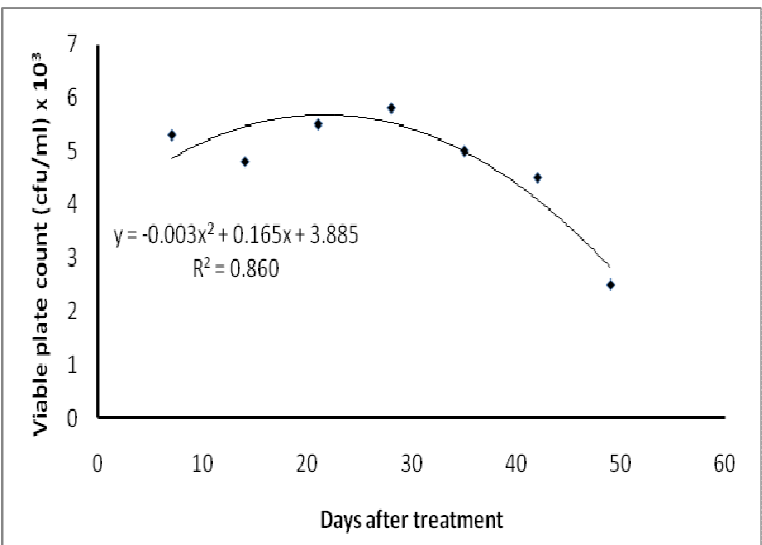

Figure 9. Viable plate count of treated waste water sample $\mathrm{C}_{1}$

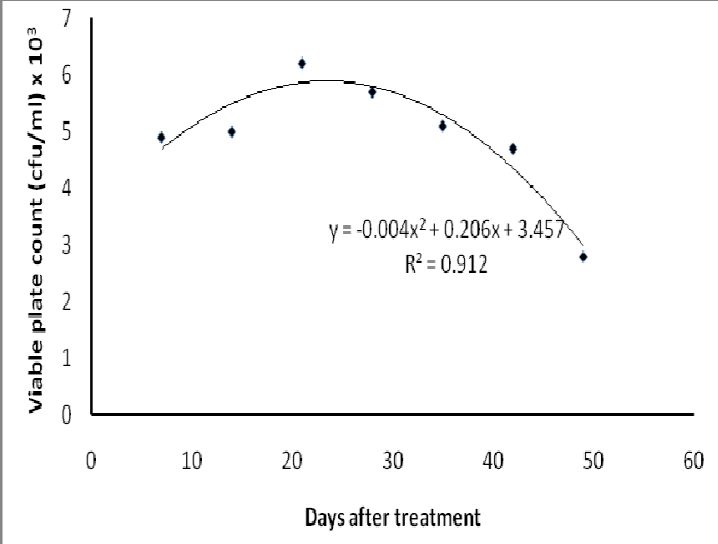

Figure 10. Viable plate count of treated waste water sample $\mathrm{C}_{2}$

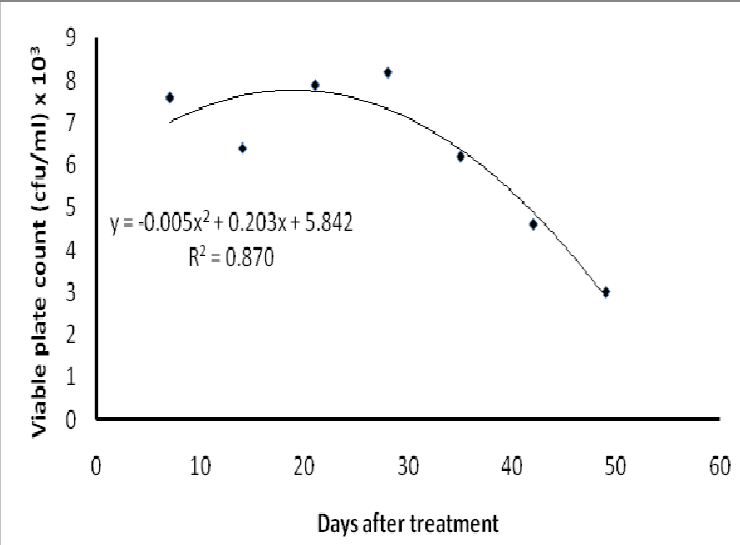

Figure 11. Viable plate connt of treated waste water sample $\mathrm{C}_{3}$ 